\title{
Distribusi Spasial, Sumber Pencemaran, dan Kajian Risiko Ekologi Polisiklik Aromatik Hidrokarbon (PAH) dalam Sedimen Pesisir di Pulau Bintan, Indonesia
}

\author{
Spatial distribution, Sources, and Ecological Risk Assessment of \\ Polycyclic Aromatic Hydrocarbons (PAHs) in Coastal Sediments of \\ Bintan Island, Indonesia
}

\author{
DENY YOGASWARA, ITA WULANDARI, KHOZANAH, EDWARD, DEDE FALAHUDIN \\ Pusat Penelitian Oseanografi - LIPI, JI. Pasir Putih 1, Ancol Timur - Jakarta Utara 14430 \\ Email: deny.yogaswara@lipi.go.id
}

\begin{abstract}
Bintan Island is the small island in the Riau Archipelago which borders Singapore and Malaysia. Its water is crossed by international shipping lines. Therefore, water quality in this area is potentially polluted by marine activities. The present study aimed to evaluate the concentration, spatial distribution, and assessment of ecological risks of polycyclic aromatic hydrocarbons (PAHs) in surface sediments from selected coastal water of Bintan. Surface sediments in this study were extracted by using the ultrasonic system and determined with GCMS. The data were visualized with ArcGIS software for spatial distribution mapping, applied ratio diagnostic methods for the source of $P A H$ contamination, and assess their ecological risk based on sediment quality guidelines. The results showed PAHs concentrations ranged from below the method detection limit ( $\angle D L)$ to $13.492 \mathrm{ng} . \mathrm{g}-1$ (dry weight) with the highest concentration of PAHs were detected at TJU 1 station as much as $13.492 \mathrm{ng} . \mathrm{g}-1$. As many as seven types of PAHs were identified in Bintan water, they were Naphthalene (two rings), Fluorene and Anthracene (three rings); fluoranthene, Pyrene, Benzo (a) Pyrene and Chrysene (five rings). Based on diagnostic ratios, the sources of PAHs in this coastal area were mainly from pyrogenic origins. Ecological risk assessment has shown that the average value of $\sum 10$ PAH in Bintan waters (5.855 ng.g-1) is lower than the corresponding ERL, ERM, TEL, and $P E L$ value indicating that the adverse biological effects of PAHs are generally low.
\end{abstract}

Keywords: Polycyclic Aromatic Hydrocarbons (PAHs), Distribution, Pollution, Bintan Waters

\begin{abstract}
ABSTRAK
Pulau Bintan merupakan pulau kecil di Kepulauan Riau yang berbatasan langsung dengan negara Singapura dan Malaysia serta perairannya dilintasi oleh jalur pelayaran internasional sehingga potensi pencemaran dari aktivitas di laut sangat tinggi. Penelitian ini bertujuan untuk mengukur konsentrasi, distribusi spasial, sumber asal pencemaran dan analisis resiko lingkungan senyawa PAH dalam sedimen permukaan di perairan pesisir Pulau Bintan. Sedimen permukaan diekstraksi dengan sistem ultrasonik dan dianalisa akhir dengan GCMS. Data senyawa PAH diolah dengan software ArGIS untuk membuat peta distribusi spasial, dianalisa dengan metode diagnosa rasio untuk mengetahui sumber pencemarnya dan dibandingkan dengan nilai baku mutu sedimen untuk mengkaji resiko ekologinya. Hasil analisis di setiap stasiun sampling di Muara Pengudang dan Tanjung Uban menunjukkan konsentrasi Total PAH (TPAH) berkisar antara < limit deteksi alat (1 ngg-1) sampai 13,492 ng.g-1 berat kering dengan konsentrasi tertinggi terdeteksi di stasiun TJU 1 yaitu sebesar 13,492 ng.g-1. Sebanyak tujuh jenis senyawa PAH teridentifikasi di perairan Bintan ini diantaranya Naphthalene, (dua cincin benzene), Fluorene dan Anthracene (tiga cincin benzene); Fluoranthene, Pyrene, Benzo (a) Pyrene, dan Chrysene (empat cincin benzene). Berdasarkan analisa diagnosa rasio, sumber pencemaran $\mathrm{PAH}$ di perairan pesisir Bintan adalah berasal dari kombinasi antara sumber pirogenik. Analisis resiko lingkungan menunjukkan nilai rata-rata $\Sigma 10 \mathrm{PAH}$ di perairan Bintan (5,855 ngg-1) masih rendah dibandingkan nilai ERL, ERM, TEL dan PEL, hal tersebut mengindikasikan bahwa efek biologis senyawa PAH secara umum rendah.
\end{abstract}

Kata kunci: Polisiklik Aromatik Hidrokarbon (PAH), Sebaran, Pencemaran, Perairan Bintan 


\section{PENDAHULUAN}

\subsection{Latar Belakang}

Senyawa polisiklik aromatik hidrokarbon (PAH) merupakan salah satu senyawa pencemar organik yang bersifat persisten, toksik, dan karsinogenik dengan berbagai variasi bentuk struktur, jenis dan toksisitasnya ${ }^{(1,3)}$. Sumber senyawa $\mathrm{PAH}$ dapat dikategorikan menjadi beberapa jenis seperti petrogenik (minyak bumi dan produk turunannya), pirogenik (pembakaran tidak sempurna bahan organik seperti kayu, rumput, batu bara), dan dapat juga berasal dari aktivitas alami di alam seperti kebakaran hutan, biogenesis, rembesan minyak bumi di dasar laut, dan letusan gunung berapi(2). Meskipun demikian, sumber antropogenik merupakan sumber utama pencemaran senyawa $\mathrm{PAH}$ yang berdampak terhadap ekosistem pesisir seperti ekosistem mangrove, lamun dan karang. Selain itu, lalu lintas kendaraan bermotor dan pembakaran batu bara telah diakui sebagai penyebab terpenting sumber pencemaran $\mathrm{PAH}$ di banyak wilayah(4,5).

Penelusuran sumber asal pencemaran senyawa $\mathrm{PAH}$ sudah dikembangkan dalam kegiatan forensik lingkungan dalam mengetahui sumber asal pencemaran $\mathrm{PAH}$. Berbagai metode yang sudah diterapkan adalah metode diagnostik rasio yang berdasarkan adanya perbedaan sifat termodinamika dari setiap individu senyawa $\mathrm{PAH}$ dan ada juga yang membandingkan nilai rasio antara kelompok senyawa $\mathrm{PAH}$ bermolekul besar dan kecil(6,7). Tingginya kadar $\mathrm{PAH}$ dalam sedimen sangat berkaitan dengan dampak biologis terhadap berbagai jenis biota. Beberapa penelitian menunjukkan bahwa senyawa $\mathrm{PAH}$ bersifat toksik terhadap ikan dan biota laut lainnya(8). Oleh karena itu, untuk menentukan status resiko dari pencemaran $\mathrm{PAH}$ terhadap kehidupan biota dan ekosistem pesisir, beberapa penelitian menggunakan metode perbandingan terhadap nilai baku mutu sudah dilakukan.

Pulau Bintan merupakan sebuah pulau kecil di Provinsi Kepulauan Riau yang memiliki luas $1.318 \mathrm{~km}^{2}$ dan secara geografis berdekatan dengan Pulau Singapura dan Pulau Batam serta dilalui jalur pelayaran dunia yang melalui Selat Malaka. Ekosistem terumbu karang, padang lamun, dan ekosistem mangrove tersebar hampir di seluruh area kawasan pesisir. Namun, tingginya aktivitas manusia, industri, dan lalu lintas perkapalan di wilayah ini khususnya wilayah Tanjung Uban dan Pengudang, menjadikan lingkungan pesisir dan lautnya yang sangat tinggi biodiversitasnya berpotensi tercemar. Kejadian tumpahan minyak dan buangan ballast water yang bercampur residu minyak bumi yang mencemari pesisir pulau Bintan telah dilaporkan ${ }^{(9)}$. Berdasarkan kondisinya tersebut, perlu diketahui seberapa besar dampak antropogenik khususnya pencemaran $\mathrm{PAH}$ di pesisir Pulau Bintan terhadap ekosistem pesisir khususnya pencemaran minyak bumi.

\subsection{Tujuan Penelitian}

Penelitian ini bertujuan untuk menentukan konsentrasi, persebaran spasial, potensi sumber asal pencemaran, dan risiko kerugian biologis dari pencemaran senyawa $\mathrm{PAH}$ dalam sedimen permukaan di pesisir Pulau Bintan, Kepulauan Riau.

\section{BAHAN DAN METODE}

\subsection{Bahan}

Pelarut dichlorometan, n-heksana, npentana, dan silica gel 60 (0,063 - 0,200 mm) (Merck, USA); bubuk alumina, activated copper (Sigma Aldrich, USA). Semua pelarut berkategori pro analis. Standard PAH yang digunakan adalah QTM PAH Mix 47930 (Sigma Aldrich, USA) yang terdiri dari naphthalene (Nap), acenaphthylene (Act), acenaphthene (Acp), fluorene (Flu), phenanthrene (Phe), anthracene (Ant), fluoranthene (Flt), pyrene (Pyr), benzo [a] anthracene $(\mathrm{BaA})$, chrysene $(\mathrm{Chr})$, benzo $[\mathrm{k}]$ fluoranthene $(\mathrm{BkF})$, benzo [a] pyrene $(\mathrm{BaP})$, indeno [1,2,3-cd] pyrene (InP), dibenzo [a,h] anthracene $(\mathrm{DaA})$, dan benzo $[\mathrm{g}, \mathrm{h}, \mathrm{i}]$ perylene (BghiP).

\subsection{Metode}

\subsubsection{Lokasi Penelitian}

Lokasi pengambilan sampel sedimen berada di pesisir Pulau Bintan bagian Utara (Muara Pengudang, $n=4$ ) dan pesisir Pulau Bintan bagian Barat (Muara Tanjung Uban, $n=4$ )

Gambar 1. Lokasi sampling sedimen pesisir

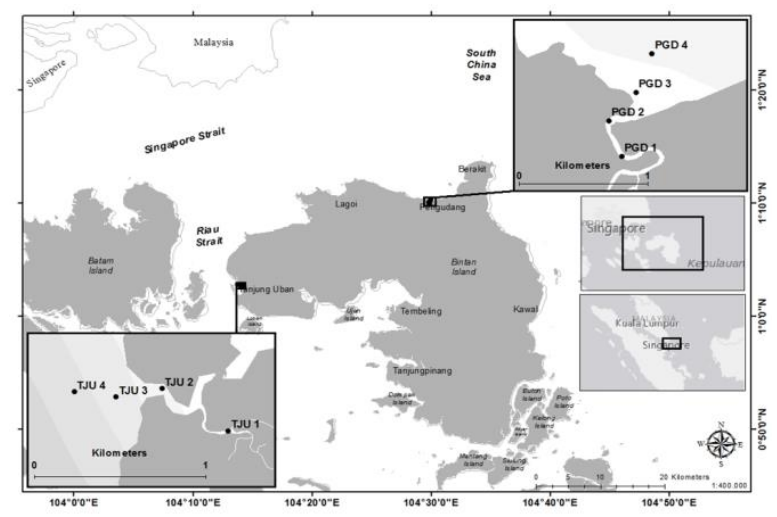

Secara umum, kedua lokasi tersebut dipilih selain untuk membandingkan lokasi dengan potensi asal pencemaran yang berbeda antara 
jalur transportasi (Muara Tanjung Uban) dan tumpahan minyak (Muara Pengudang), serta untuk mengetahui distribusi sebarannya dari setiap muara.

\subsubsection{Pengambilan sampel}

Sampel sedimen permukaan diambil dari muara sampai estuari menggunakan alat Van Veen Grab. Sedimen permukaan dengan kedalaman sekitar $5 \mathrm{~cm}$ diambil menggunakan sendok alumunium dan langsung disimpan dalam botol kaca yang sebelumnya sudah dicuci dengan detergen Teepol dan dibilas dengan pelarut diklorometana (DCM). Setelah itu, botol sampel disimpan dalam ice box berpendingin suhu $4^{\circ} \mathrm{C}$ untuk selanjutnya dianalisis di laboratorium.

\subsubsection{Analisa Kadar Air dan Ukuran Partikel Sedimen}

Pemisahan ukuran partikel sedimen dilakukan dengan metode granulometri. Secara detail, sedimen ditimbang dan dikeringkan dengan oven pada suhu $80^{\circ} \mathrm{C}$ selama $12 \mathrm{jam}$, lalu dihomogenkan dengan air dan disaring dengan ayakan bertingkat berukuran mesh $8 ; 4 ; 2 ; 1 ; 0,5$; 0,$25 ; 0,125$; dan 0,063 mm. Pengelompokan ukuran butir dilakukan berdasarkan klasifikasi Wentworth ${ }^{(10,11)}$.

Adapun untuk pengukuran kadar air, sedimen basah ditimbang sebanyak $2 \mathrm{gr}$ dan dikeringkan dengan oven suhu pada $105^{\circ} \mathrm{C}$ selama 12 jam. Berdasarkan hasil pengukuran kadar air digunakan untuk mengukur konsentrasi $\mathrm{PAH}$ dalam berat kering sedimen.

\subsubsection{Analisis $\mathrm{PAH}$}

Prosedur analisa PAH dalam sedimen mengacu pada metode yang lakukan oleh Yamaguchi dan Lee ${ }^{(12)}$. Sebanyak 10 gram sampel berat kering dihomogenkan dalam lumpang dan ditambahkan sodium sulfat, lalu dimasukkan ke dalam gelas Erlenmeyer dan diekstraksi dengan alat ultrasonik masingmasing secara berurutan menggunakan $30 \mathrm{ml}$ pelarut DCM, $n$-heksana, dan campuran DCM: $n$ heksana (v/v: 1/1). Hasil ekstraksi lalu diuapkan dengan alat rotary evaporator sampai $1 \mathrm{ml}$. Hasil ekstraksi lalu di clean up dan difraksinasi dengan kolom kromatografi yang terdiri dari glasswool, bubuk Silika gel 60 (Ukuran partikel: 0,063-0,200 $\mathrm{mm})$, bubuk alumina, dan activated copper. Pelarut $n$-pentana digunakan untuk elusi fraksi 1 dan campuran n-pentana:DCM (60:40 v/v) untuk fraksi 2. Selanjutnya, hasil fraksi 2 diuapkan sampai $1 \mathrm{ml}$ dan langsung diinjeksikan ke dalam alat Gas Chromatography Mass Spectrometer (GCMS). GCMS yang digunakan menggunakan kolom TG5-SilMS dengan kondisi yaitu panjang kolom (length): $30 \mathrm{~m}$; ID: 0,25 mm; Film: 0,25 um.; Oven: $50^{\circ} \mathrm{C}(0,5$ menit), laju gas (gas rate): $160^{\circ} \mathrm{C}$ (15 menit) $\rightarrow 290^{\circ} \mathrm{C}$ (13 menit) $\rightarrow 300^{\circ} \mathrm{C}$ (4 menit). Untuk gas system, yaitu: Helium 1,2 $\mathrm{ml} / \mathrm{min}$ (constant flow); Split flow: $10 \mathrm{ml} / \mathrm{min}$; Splitless time: 0,5 menit. Konsentrasi PAH dinyatakan dalam ng.g-1 berat kering (bk).

\subsubsection{Kendali Mutu (QC)}

Kalibrasi standar eksternal menggunakan standar QTM PAH mixture 47930. Hasil kalibrasi kurva standar $\mathrm{PAH}$ dengan variasi konsentrasi 10, 100, 500, dan $1000 \mathrm{ng} \cdot \mathrm{g}^{-1}$ didapatkan nilai $\mathrm{R}^{2}$ masing senyawa $\mathrm{PAH}$ yaitu Nap $(0,9995)$, Act $(0,9923)$, Acp $(0,9885)$, Flu $(0,9853)$, Ant $(0,9905)$, Phe $(0,9918)$, Flt $(0,9875)$, Pyr $(0,9944), \mathrm{BaA}(0,9972), \mathrm{Chr}(0,9968), \mathrm{BkF}$ $(0,9938)$, BaP $(0,9797), \operatorname{DaA}(0,9767), \operatorname{In} P$ $(0,8349)$, BghiP $(0,9794)$. Sebanyak tiga sampel blanko digunakan pada proses analisis sampel. Penambahan internal standar yang digunakan yaitu Naphthalene-d8, acenaphthene-d10, phenanthrene-d10, chrysene-d12, dan perylened12 sebelum diinjeksikan ke alat GCMS.

\subsubsection{Identifikasi Sumber Pencemar PAH}

Sumber pencemaran senyawa PAH di lingkungan dapat dibedakan menjadi pirogenik dan petrogenik berdasarkan diagnosis rasio (Tabel 1). Beberapa rasio isomer yang digunakan adalah Ant/(Ant+Phe), Flt/(Flt+Pyr), $\mathrm{B}[\mathrm{a}] \mathrm{A} /(\mathrm{B}[\mathrm{a}] \mathrm{A}+$ Chry), Ind/(Ind+B[g,h,i]P) dan Total Low Molecular Weigth ( $(\mathrm{LMW}) /$ total High Molecular Weigth $(\Sigma \mathrm{HMW})^{(6,13)}$.

\subsubsection{Analisa Risiko Lingkungan}

Untuk mengetahui potensi dampak dari individu senyawa PAH yang ada dalam sedimen terhadap kesehatan ekosistem pesisir, analisis risiko lingkungan dilakukan dengan membandingkan konsentrasi rata-rata individu $\mathrm{PAH}$ dalam sedimen dengan nilai ERL (Effect range-low), ERM (Effect range-median) ${ }^{(14)}$, TEL (Threshold effect levels), dan PEL (Probable effect levels) ${ }^{(15)}$. Keempat nilai tersebut dapat digunakan untuk mengklasifikasikan konsentrasi $\mathrm{PAH}$ dan memprediksi dampaknya, misalkan nilai rata-rata $\mathrm{PAH}$ kurang dari nilai $\mathrm{ERL}$ atau TEL dikategorikan sebagai kelompok di bawah 
ambang batas yang mana dampak biologis akan jarang terjadi, nilai rata-rata PAH antara nilai TEL atau ERL dan PEL atau ERM dikategorikan sebagai kelompok pertengahan ambang batas dengan dampak biologis kemungkinan terjadi, dan jika nilai rata-rata PAH nya lebih dari ERM atau PEL, dikelompokkan sebagai kelompok diatas ambang batas yang mana dampak biologisnya akan terjadi( ${ }^{(14)}$.

Tabel 1. Identifikasi rasio biner senyawa $\mathrm{PAH}$ terhadap asal sumber pencemaran

\begin{tabular}{ll}
\hline \multicolumn{1}{c}{ Rasio PAH } & \multicolumn{1}{c}{$\begin{array}{c}\text { Potensi Sumber } \\
\text { Asal }\end{array}$} \\
\hline$\sum \mathrm{LMW} / \sum \mathrm{HMW}<1$ & Pirogenik $^{(13)}$ \\
$\sum \mathrm{LMW} / \sum \mathrm{HMW}>1$ & Petrogenik $^{(13)}$
\end{tabular}

\section{HASIL DAN PEMBAHASAN}

\subsection{Karakteristik Sedimen}

Karakteristik ukuran partikel sedimen wilayah Tanjung Uban dan Pengudang sebagian besar terdiri dari pasir dengan persentase berurutan adalah $49,51 \%$ dan $85,36 \%$ (Gambar 2). Secara umum, pasir memiliki nilai karbon organik yang rendah sehingga mengikat lebih sedikit pencemar organik yang sangat berkaitan dengan nilai TOC (Total Organic Carbon) dalam sedimen. Namun, dari hasil penelitian ini menunjukkan hal berbeda karena misalkan pada stasiun TJU 1 yang merupakan stasiun dengan konsentrasi total PAH tertinggi, memiliki karakteristik sedimen dengan komposisi pasir sebagai penyusun dominan (> 60\%). Hal tersebut juga didapatkan dari penelitian yang lain bahwa hasil uji statistik menunjukkan tidak ada korelasi positif antara jumlah total PAH dengan karakteristik dari jenis penyusun sedimennya(21). Menurut Gstafsson, et al.(22) dan Lohman et al.(23) karakteristik sedimen seperti ukuran partikel memiliki pengaruh yang kecil terhadap akumulasi $\mathrm{PAH}$ dalam sedimen.

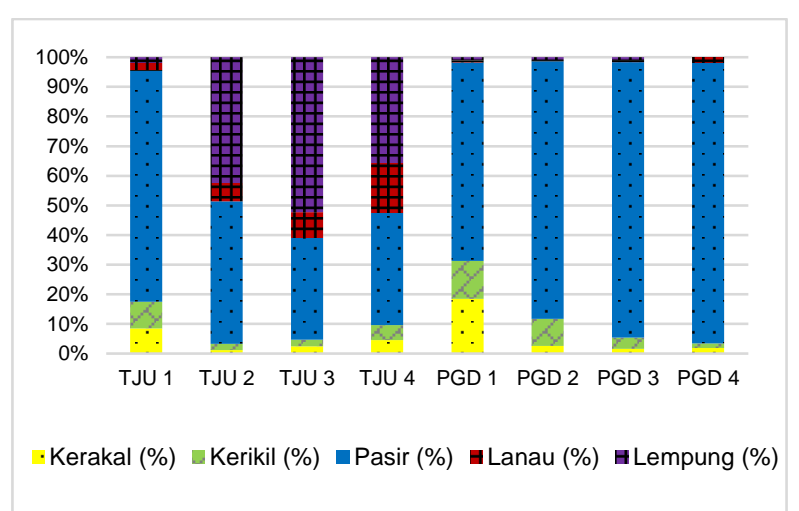

Gambar 2. Karakteristik sedimen permukaan berdasarkan grain size menurut Wentwort $(10,11)$

\subsection{Identifikasi dan Karakterisasi PAH}

Analisis senyawa PAH dalam sedimen menggunakan GCMS dapat diidentifikasi secara kualitatif melalui hasil kromatogram (Gambar 3). Selain itu, massa molekul dari masing-masing ion dapat digunakan sebagai konfirmasi jenis senyawa $\mathrm{PAH}$ yang diidentifikasi (Tabel 2).

Sedimen permukaan dapat merefleksikan status pencemaran terkini dari suatu lokasi. Sebanyak tujuh dari lima belas jenis PAH yang di analisis teridentifikasi dalam sedimen permukaan dengan berbagai variasi konsentrasi. Senyawa PAH jenis Pyrene merupakan senyawa dengan konsentrasi total tertinggi yaitu sebesar 20,027 ng. $\mathrm{g}^{-1} \mathrm{bb}(34 \%)$ untuk keseluruhan total sampel sedimen yang dianalisis. Konsentrasi Pyrene yang tinggi disebabkan karena senyawa ini umumnya sering terdapat di lingkungan akibat dari proses pembakaran yang tidak sempurna dari mesin kendaraan bermotor dan juga dihasilkan dari tumpahan minyak bumi(24,25). Sementara senyawa Chrysene merupakan senyawa dengan konsentrasi total terendah yaitu sebesar 1,951 ng.g ${ }^{-1} \mathrm{bb}(3 \%)$ (Gambar 4). 


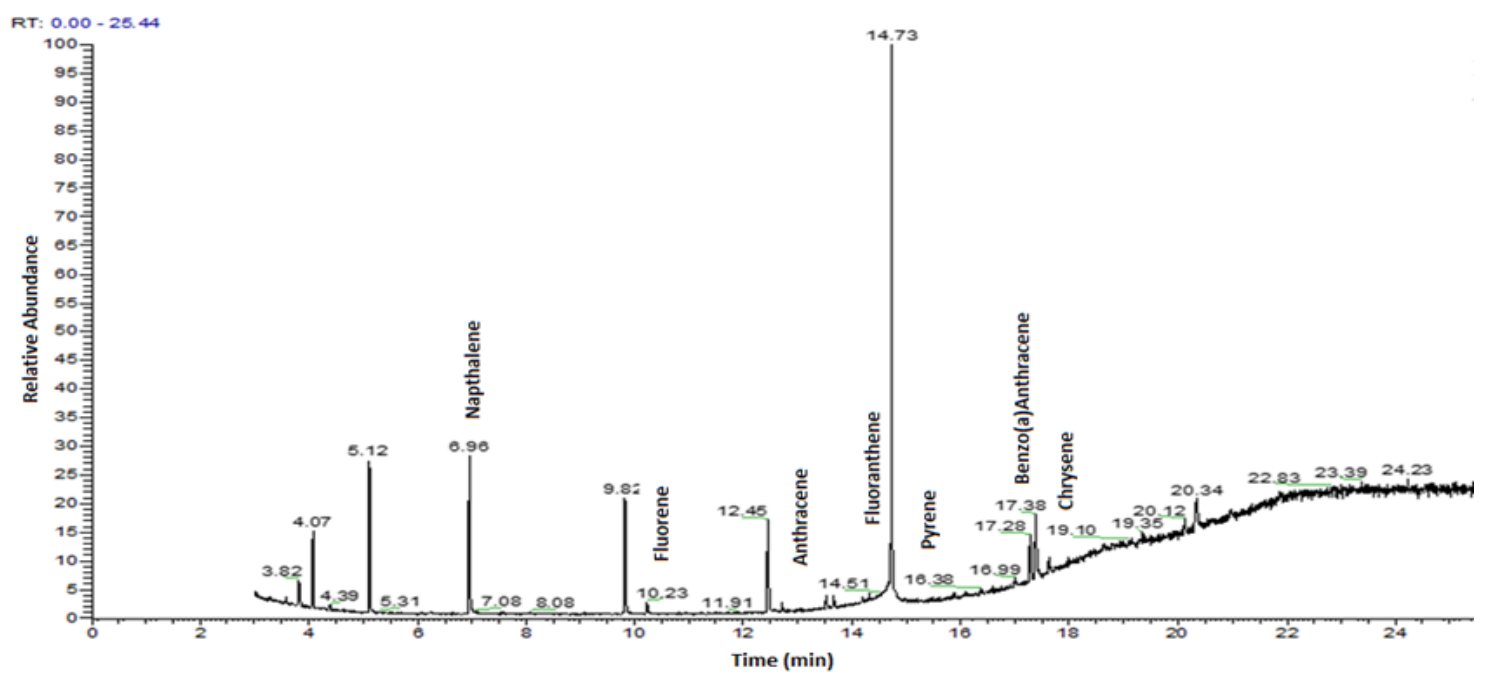

Gambar 3. Hasil Kromatogram PAH dari analisis instrumen GCMS

Ketujuh jenis senyawa $\mathrm{PAH}$ yang teridentifikasi ini memiliki karakteristik yang berbeda antara jenis yang satu dengan lainnya. Senyawa Naftalena, Fluorena, dan Anthracene memiliki susunan dua dan tiga cincin benzena yang linier yang masuk dalam kategori Low Molecular Weight (LMW)(2,26). Sementara senyawa Fluoranthene, Pyrene, Benzo (a) Anthracene, dan Chrysene memiliki susunan empat cincin benzena berstruktur angular dan cluster yang masuk dalam kategori High Molecular Weight (HMW).

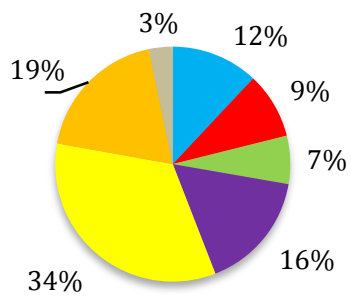

$\square$ Nap $\square$ Flu $\square$ Ant $\square$ Flt $\square$ Pyr $\square$ BaA $\square$ Chr

Gambar 4. Komposisi senyawa PAH dalam sedimen permukaan
Tabel 2. Identifikasi massa molekul senyawa PAH melalui ion kuantifikasi dan konfirmasi

\begin{tabular}{lcc}
\hline \multicolumn{1}{c}{ Senyawa PAH } & $\begin{array}{c}\text { Ion } \\
(\mathrm{m} / \mathrm{z})\end{array}$ & $\begin{array}{c}\text { Ion Konfirmasi } \\
(\mathrm{m} / \mathrm{z})\end{array}$ \\
\hline Nap & 128 & $127 ; 129 ; 51$ \\
\hline Act & 152 & $153 ; 151 ; 76$ \\
\hline Acp & 154 & $153 ; 152 ; 76$ \\
\hline Flu & 166 & $166 ; 167 ; 82$ \\
\hline Ant & 178 & $89 ; 179 ; 176$ \\
\hline Phe & 178 & $176 ; 179 ; 176$ \\
\hline Flt & 202 & $203 ; 101 ; 200$ \\
\hline Pyr & 202 & $203 ; 101 ; 200$ \\
\hline BaA & 228 & $229 ; 114 ; 226$ \\
\hline Chr & 228 & $229 ; 114 ; 226$ \\
\hline BkF & 252 & $253 ; 125 ; 250$ \\
\hline BaP & 252 & $253 ; 126 ; 250$ \\
\hline InP & 276 & $138 ; 277 ; 274$ \\
\hline Dibenzo (ah) & $278 ; 279 ; 276$ \\
\hline Anthracene (DaA) & & \\
\hline & & $138 ; 277 ; 137$ \\
\hline
\end{tabular}




\subsection{Konsentrasi dan Distribusi PAH}

Penentuan konsentrasi PAH secara kuantitatif menunjukkan bahwa konsentrasi total $\mathrm{PAH}$ (TPAH) tertinggi terdeteksi di stasiun TJU 1 Muara Tanjung Uban yaitu sebesar 13,492 $\mathrm{ng}^{-\mathrm{g}^{-1}}$ berat basah. Hal ini dimungkinkan terjadi karena menurut Baek(27) dan Khozanah(28), lokasi dekat muara sungai umumnya merupakan tempat terakumulasinya polutan PAH. Lokasi stasiun TJU 1 ini merupakan lokasi yang dekat dengan muara sungai dan tempat terjadinya proses akumulasi sedimen baik yang berasal dari daratan yang dibawa oleh arus sungai maupun yang berasal dari muara laut. Sementara konsentrasi total PAH terendah terdapat di stasiun PGD 2 yaitu kurang dari 1 ng.g-1 (Gambar 5 dan 6).

Distribusi senyawa PAH terjadi secara merata di setiap stasiun. Di stasiun TJU 1 merupakan lokasi dengan distribusi senyawa PAH terbanyak yaitu sebanyak lima jenis dari tujuh jenis yang teridentifikasi yaitu Naphthalene, Fluorene, Benzo (a) Anthracene, Pyrene, dan Chrysene. Sementara di stasiun PGD 2 hanya terdeteksi satu jenis senyawa PAH yaitu Naphthalene (Gambar 7).

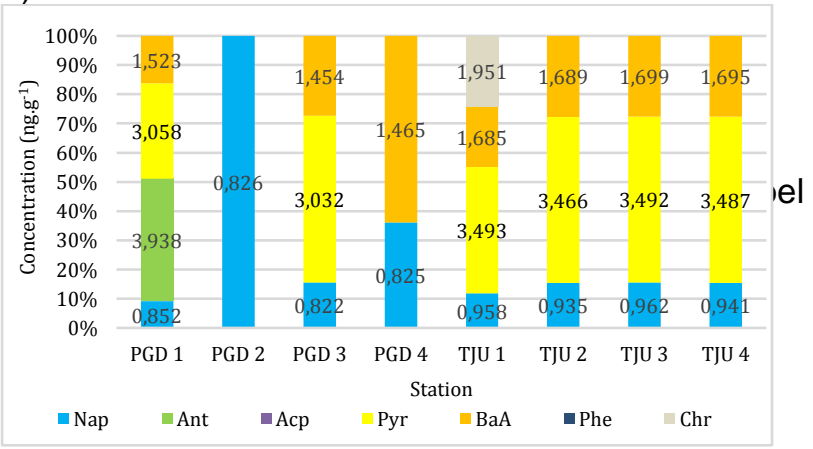

Gambar 5. Konsentrasi Total PAH ( $\mathrm{PAH}$ ) di Muara Pengudang dan Tanjung Uban, Pulau Bintan

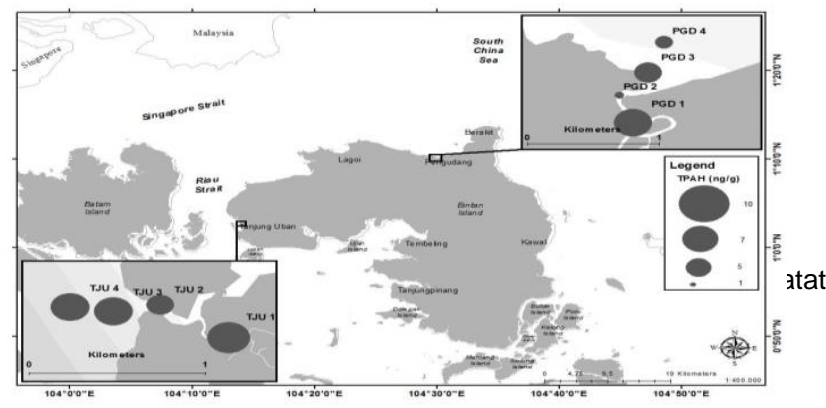

Gambar 6. Distribusi spasial konsentrasi total $\mathrm{PAH}$ dalam sedimen

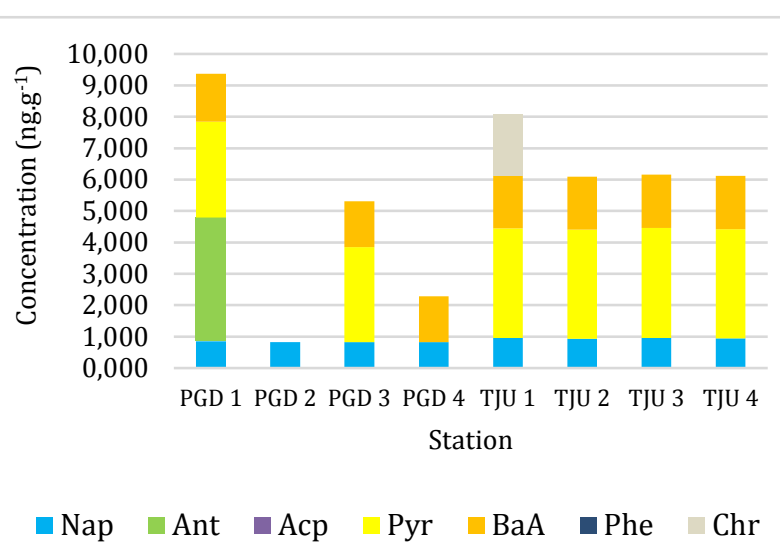

Gambar 7. Distribusi jenis PAH dalam sedimen di perairan Pengudang dan Tanjung Uban, Pulau Bintan

\subsection{Analisis Sumber Pencemaran PAH}

Berdasarkan rasio PAH pada Tabel 3, secara umum sumber asal pencemaran PAH di muara Pengudang dan Tanjung Uban didominasi oleh sumber yang berasal dari proses pirogenik seperti pembakaran tidak sempurna bahan bakar minyak bumi atau tumbuhan. Menurut Yunker, et. al.(6) bahwa PAH dalam sedimen umumnya berasal dari pembakaran biomasa, pembakaran batu bara dan petroleum.

Tabel 2 Hasil perhitungan rasio binary PAH untuk menentukan sumber cemaran

\begin{tabular}{lllll}
\hline Rasio/Stasion & PGD & PGD & PGD & PGD \\
& 1 & 2 & 3 & 4 \\
\hline$\sum$ LMW/ $\Sigma$ HMW & 1 & - & 0.2 & 0.6 \\
Ant/(Ant+Phe) & 1 & - & - & - \\
B[a]A/(B[a]A+Chry) & 1 & - & 1 & 1 \\
\hline Rasio/Stasion & TJU & TJU & TJU & TJU \\
\hline$\sum$ LMW/ $\sum$ HMW & 0.9 & 0.2 & 0.1 & 0.1 \\
Flt/(Flt+Pyr) & - & - & 0.6 & 0.6 \\
B[a]A/(B[a]A+Chry) & 0.5 & 1 & 1 & 1 \\
\hline an: - = tidak dapat dihitung & & &
\end{tabular}

\subsection{Analisis resiko lingkungan}

Hasil rata-rata total $\Sigma 10 \mathrm{PAH}$ di perairan Bintan (Pengudang dan Tanjung Uban) yaitu sebesar 5,855 ng.g-1 bk. Nilai rata $\sum 10 \mathrm{PAH}$ ini 587 kali lebih rendah dibandingkan dengan nilai standar ERL (Effect Range Low), 3361 kali lebih 
rendah dari nilai standar ERM (Effect Range Median), 116 kali lebih rendah dari nilai standar TEL (Threshold Effect Levels), dan 1045 kali lebih rendah dari standar nilai PEL (Probable Effect Levels) (Tabel 4). Nilai ERL dan ERM dapat digunakan sebagai evaluasi toksisitas dalam sedimen laut. Nilai ERL menunjukkan konten nilai bawah yang efek toksiknya sangat jarang terdeteksi, sementara nilai ERM menganalisis nilai atas yang efeknya sering terdeteksi(14,29).

Table 4. Perbandingan konsentrasi jenis $\mathrm{PAH}$ dalam sedimen terhadap kriteria standar pencemaran (ng.g-1 berat kering)

\begin{tabular}{|c|c|c|c|c|c|}
\hline Senyawa & ERLa & ERMa & TELb & PELb & Nilai \\
\hline Phe & 240 & 1.500 & 86,7 & 544 & - \\
\hline Ant & 85,3 & 1.100 & 46,9 & 245 & 0,492 \\
\hline Flt & 600 & 5.100 & 113 & 1.494 & 1,214 \\
\hline Pyr & 665 & 2.500 & 153 & $1 . .398$ & 2,503 \\
\hline$B(a) A$ & 261 & 1.600 & 74,8 & 693 & 1,401 \\
\hline Chr & 384 & 2.800 & 108 & 846 & 0,244 \\
\hline $\mathrm{B}(\mathrm{k}) \mathrm{F}$ & 280 & 1.620 & - & - & - \\
\hline$B(a) P$ & 430 & 1.600 & 88,8 & 763 & - \\
\hline$D(a h) A$ & 430 & 1.600 & 6,22 & 135 & - \\
\hline$B$ (ghi)P & 63,4 & 260 & - & - & - \\
\hline$\Sigma 10 \mathrm{PAH} \mathrm{C}$ & $3.438,7$ & 19.680 & 677,42 & 6118 & 5,855 \\
\hline $\begin{array}{l}\text { a Effect ra } \\
\text { values (14 } \\
\text { b Thresholo } \\
\text { levels valu } \\
\text { c Penjumlar } \\
\text { Chry, B(k) }\end{array}$ & $\begin{array}{l}\text { ige-low } \\
\text { effect } \\
\text { s (15) } \\
\text { an dari } \\
B(a) P\end{array}$ & $\begin{array}{l}\text { dan } \\
\text { levels }\end{array}$ & $\begin{array}{l}\text { it, Fluo } \\
\mathrm{B} \text { (ghi) }\end{array}$ & able & $\begin{array}{l}\text { ian } \\
\text { ect }\end{array}$ \\
\hline
\end{tabular}

\section{KESIMPULAN}

Hasil analisis senyawa PAH di perairan Bintan (Pengudang dan Tanjung Uban) menunjukkan konsentrasi PAH tertinggi terdeteksi di stasiun TJU 1 di Muara Tanjung Uban yaitu sebesar 13,492 ng.g-1. Distribusi senyawa PAH tersebar secara merata di setiap stasiun sampling di Muara Pengudang dan Tanjung Uban dengan rentang $<1$ - 13,492 ng.g-1. Sebanyak tujuh jenis senyawa PAH terid.ntifikasi di perairan Bintan ini diantaranya Naphthalene (dua cincin benzene), Fluorene dan Anthracene (tiga cincin benzene); Fluoranthene, Pyrene, Benzo (a) Pyrene, dan Chrysene (empat cincin benzene). Sumber pencemaran $\mathrm{PAH}$ di perairan Bintan umumnya berasal dari pembakaran biomasa dan buangan kendaraan bermotor. Hasil analisis resiko lingkungan menunjukkan nilai rata-rata $\sum_{10} \mathrm{PAH}$ di perairan Bintan sebesar 5,855 ng.g ${ }^{-1}$. Nilai ini mengindikasikan bahwa efek biologis senyawa $\mathrm{PAH}$ secara umum rendah.

\section{PERSANTUNAN}

Penulis mengucapkan terima kasih kepada Pusat Penelitian Oseanografi - LIPI dan seluruh tim sehingga kegiatan penelitian ini berjalan dengan sukses, Penelitian ini didanai dari dana penelitian Prioritas LIPI melalui program COREMAP-CTI tahun 2018.

\section{DAFTAR PUSTAKA}

1. Abdel-Shafy, H.I., \& Mansour, M.S.M. (2015). A review on polycyclic aromatic hydrocarbons: Source, environmental impact, effect on human health and remediation. Egypt Journal of Petroleum, https://doi.org/10.1016/j.ejpe.2015.03.011.

2. Deng, W., Li, X.G., Li, S.Y., Ma, Y.Y., \& Zhang, D.H. (2013). Source apportionment of polycyclic aromatic hydrocarbons in surface sediment of mud areas in the East China Sea using diagnostic ratios and factor analysis Marine Pollution Bulletin, 70(1-2), 266-273, https://doi.org/10.1016/j.marpolbul.2013.02.03 2.

3. Mu, L., Peng, L., Liu, X., Song, C., Bai, H., Zhang, J., Hu, D., He, Q., \& Li, F. (2014). Characteristics of polycyclic aromatic hydrocarbons and their gas/particle partitioning from fugitive emissions in coke plants Atmospheric Environment, 83, 202-210, https://doi.org/10.1016/j.atmosenv.2013.09.04 3.

4. Lithner, D., Larsson, A., \& Dave, G. (2011). Environmental and health hazard ranking and assessment of plastic polymers based on chemical composition. Science of the Total Environment, 409(18), 3309-3324, https://doi.org/10.1016/j.scitotenv.2011.04.038

5. Gu, Y.G., Lin, Q., Lu, T.T., Ke, C.L., Sun, R.X., \& Du, F.Y. (2013). Levels, composition profiles and sources of polycyclic aromatic hydrocarbons in surface sediments from Nan'ao Island, a representative mariculture base in South China Marine Pollution Bulletin, 75(1-2), 310-316, https://doi.org/10.1016/j.marpolbul.2013.07.03 
9.

6. Yunker, M.B., Macdonald, R.W., Vingarzan, R., Mitchell, H., Goyette, D., \& Sylvestre, S. (2002). PAHs in the Fraser River basin: a critical appraisal of $\mathrm{PAH}$ ratios as indicators of PAH source and composition .33, 489-515.

7. Yunker MB, \& Macdonald RW. (2003). Petroleum biomarker sources in suspended particulate matter and sediments from the Fraser River Basin and Strait of .Organic Geochemistry, 34, 1525-1541, https://doi.org/10.1016/S01466380(03)00157-8.

8. Sun R, Sun Y, Li QX, Zheng X, Luo X, \& Mai B. (2018). Science of the Total Environment Polycyclic aromatic hydrocarbons in sediments and marine organisms: Implications of anthropogenic effects on the coastal environment .Science of the Total Environment, 640-641, 264-272, https://doi.org/10.1016/j.scitotenv.2018.05.320

9. Mujahidawati. (2018). Kajian sumberdaya pesisir dan laut akibat pencemaran di perairan kecamatan gunung kijang kabupaten bintan .Institut Pertanian Bogor.

10.Wentworth CK. (1922). A Scale of Grade and Class Terms for Clastic Sediments .Journal of Geology, 377-392.

11.Blair TC, \& Mcpherson JG. (1999). Grain-size and textural classification of coarse sedimentary particles GRAIN-SIZE AND TEXTURAL CLASSIFICATION OF COARSE SEDIMENTARY PARTICLES .Journal of Sedimentary Research, 69(January), 6-19, https://doi.org/10.2110/jsr.69.6.

12.Yamaguchi C, \& Lee W. (2010). A cost effective, sensitive, and environmentally friendly sample preparation method for determination of polycyclic aromatic hydrocarbons in solid samples .Journal of Chromatography A, 1217(44), 6816-6823, https://doi.org/10.1016/j.chroma.2010.08.055.

13. Xue R, Chen L, Lu Z, Hang J, Yang H, \& Zhang J. (2016). Spatial distribution and source apportionment of PAHs in marine surface sediments of Prydz Bay, East Antarctica .Environmental Pollution, 1-9, https://doi.org/10.1016/j.envpol.2016.05.084.
14.Long ER, Bin C, Smith SL, \& Calder FD. (1995). Incidence of Adverse Biological Effects Within Ranges of Chemical Concentrations in Marine and Estuarine Sediments .19(1), 8197.

15.Macdonald, D.D., Carr, R.S., Calder, F.D., Long, E.R., \& Ingersoll, C,G. (1996). Development and evaluation of sediment quality guidelines for Florida coastal waters .Ecotoxicology, 5, 253-278.

16.Pies, C., Hoffmann, B., Petrowsky, J., Yang, Y., Ternes, T.A., \& Hofmann, T. (2008). Characterization and source identification of polycyclic aromatic hydrocarbons (PAHs) in river bank soils .Chemosphere, 72(10), 15941601 , https://doi.org/10.1016/J.CHEMOSPHERE.20 08.04.021.

17.Akyüz M, \& Çabuk H. (2010). Gas-particle partitioning and seasonal variation of polycyclic aromatic hydrocarbons in the atmosphere of Zonguldak, Turkey .Science of The Total Environment, 408(22), 5550-5558, https://doi.org/10.1016/j.scitotenv.2010.07.063

18.Ravindra, K., Sokhi, R., \& Van, G. R. (2008). Atmospheric polycyclic aromatic hydrocarbons: Source attribution, emission factors and regulation .Atmospheric Environment, 42(13), 2895-2921, https://doi.org/10.1016/J.ATMOSENV.2007.12 .010 .

19.De La Torre-Roche, R.J., Lee, W.Y., \& Campos-Díaz, S.I. (2009). Soil-borne polycyclic aromatic hydrocarbons in El Paso, Texas: Analysis of a potential problem in the United States/Mexico border region .Journal of Hazardous Materials, 163(2-3), 946-958, https://doi.org/10.1016/J.JHAZMAT.2008.07.0 89.

20.Katsoyiannis, A., Terzi, E., \& Cai, Q.Y. (2007). On the use of $\mathrm{PAH}$ molecular diagnostic ratios in sewage sludge for the understanding of the $\mathrm{PAH}$ sources. Is this use appropriate? .Chemosphere, 69(8), 1337-1339, https://doi.org/10.1016/J.CHEMOSPHERE.20 07.05.084.

21.Gu, Y., Li, H., \& Lu, H. (2017). Polycyclic aromatic hydrocarbons ( PAHs) in surface 
sediments from the largest deep plateau lake in China: Occurrence, sources and biological risk .Ecological Engineering, 101, 179-184, https://doi.org/10.1016/j.ecoleng.2017.02.007.

22.Gustafsson, O., Haghseta, F., Chan, C., Macfarlane, J., \& Gschwend, P.M. (1997). Quantification of the Dilute Sedimentary Soot Phase: Implications for PAH Speciation and Bioavailability .31(1), 203-209.

23.Lohmann, R., Macfarlane, J.K., \& Gschwend, P.M. (2005). Importance of Black Carbon to Sorption of Native PAHs, PCBs, and PCDDs in Boston and New York Harbor Sediments .39(1), 141-148.

24.Lease, C.W.M., Bentham, R.H., Gaskin, S.E., \& Juhasz, A.L. (2011). Isolation and Identification of Pyrene Mineralizing Mycobacterium spp. from Contaminated and Uncontaminated Sources .Applied and Environmental Soil Science, 2011(January 2014), https://doi.org/10.1155/2011/409643.

25.Abo-State, M.A.M, El-Dars, F.M.S.E., \& Abdin, B.A. (2018). Isolation and Identification of Pyrene Degrading Bacteria and its Pathway from Suez Oil Processing Company, Suez, Egypt. .Journal of Ecology of Health \&
Environment, 6(2), 63-76, https://doi.org/10.18576/jehe/060202.

26.Tobiszewski, M. \& Namieśnik, J. (2012). PAH diagnostic ratios for the identification of pollution emission sources .Environmental Pollution, 162, 110-119, https://doi.org/10.1016/j.envpol.2011.10.025.

27.Baek, S.O., Field, R.A., Goldstone, M.E., Kirk, P.W., Lester, J.N., \& Perry, R. (1991). A review of atmospheric polycyclic aromatic hydrocarbons: sources, fate and behavior .Water, Air, and Soil Pollution, 60, 279-300.

28.Munawir, K., \& Yogaswara, D. (2018). Concentrations of PAHs (Polycyclicaromatic Hydrocarbons) Pollutant in Sediment of The Banten Bay .Bull Mar Geol, https://doi.org/10.32693/bomg.32.2.2017.377.

29.Pongpiachan, S., Hattayanone, M., Tipmanee, D., Suttinun, O., \& Khumsup, C. (2017). Chemical characterization of polycyclic aromatic hydrocarbons (PAHs) in 2013 Rayong oil spill-affected coastal areas of Thailand .Environmental Pollution, xxx, 1-11, https://doi.org/10.1016/j.envpol.2017.09.096. 
